\title{
上咽頭癌の治療後に出現した放射線脊䯣症例
}

\author{
坂本 雅之 ${ }^{1)}$ - 阿部 和也 ${ }^{1)}$ - 西村 信一2) - 北原 伸郎3)
}

\section{A Case of Radiation Myelopathy Induced by Radiotherapy to Nasopharyngeal Carcinoma}

\author{
Masayuki Sakamoto and Kazuya Abe \\ (Tokyo Metropolitan Fuchu Hospital) \\ Shinichi Nishimura \\ (Kameda General Hospital) \\ Nobuo Kitahara \\ (Showa Public Hospital)
}

\begin{abstract}
We described a case of radiation myelopathy occurring after radiotherapy of $70 \mathrm{~Gy}$ to the nasopharyngeal carcinoma. Because the cervical spine was included in the radiation area, the neurological symptoms of the area progressed, and MRI did not reveal the recurrent tumor compressing the cervical spine, the condition was diagnosed as radiation myelopathy. Although oral medication of a corticosteroid failed to reverse the progression of the myelopathy, the patient is able to move about inside or outside the home with a wheelchair.
\end{abstract}

Key words : radiation myelopathy, radiotherapy, nasopharyngeal carcinoma, cervical spine, MRI

はじめに

上咽頭癌の治療は，手術操作がしにくい領域に発生す ることと，放射線に対して高い感受性を持つことから放 射線治療が中心となる．早期に頸部所属リンパ節への転 移が生じるため，頭蓋底から全頸部を含む範囲が照射野 となることが多い，そのため，頸部脊髄への放射線の照 射が行われ，まれに放射線治療後に脊䯣症を合併する症 例が報告されている1).われわれは上咽頭癌の治療とし て許容量とされる計 $70 \mathrm{~Gy}$ の外照射を施行し，その19 カ月後に放射線脊䯣症が出現した症例を経験したので, 若干の文献的考察を加光て報告する.

\section{症例}

症例 : 50 歳, 男性.
主訴 : 鼻出血, 左耳閉感.

既往歴 : 30 歳頃から慢性腎炎, 腎性高血厌.

家族歴：特記すべきことなし。

現病歴: 平成 7 年秋頃より, 飲酒後に鼻出血が出現す るようになった。平成 8 年 7 月に近医耳鼻咽喉科を受診, 上咽頭の腫瘍を指摘されたが放置していた. 鼻出血の頻 度が増加し, 左耳閉感も出現したため, 平成 8 年 8 月当 科初診した。

初診時, 左ローゼンミュラー窩に易出血性の腫瘍を認 めた. MRI 飞て腫瘍の内頸動脈周囲, 耳下腺深葉への 浸潤, 頸部リンパ節転移を認め, 上咽頭癌 $\mathrm{T} 2 \mathrm{~N} 2 \mathrm{cM} 0$ と診断された(図 1 ). 腫瘍は病理組織学的に低分化扁平 上皮癌と診断され，化学療法(THP $50 \mathrm{mg}$, CBDCA 600 $\mathrm{mg}, \mathrm{PEP} 5 \mathrm{mg} \times 4$ 日間)を 2 クール施行後, 平成 8 年

1）東京都立府中病院耳鼻咽喉科

2) 亀田総合病院耳鼻咽喉科

3）公立昭和病院耳鼻咽喉科 


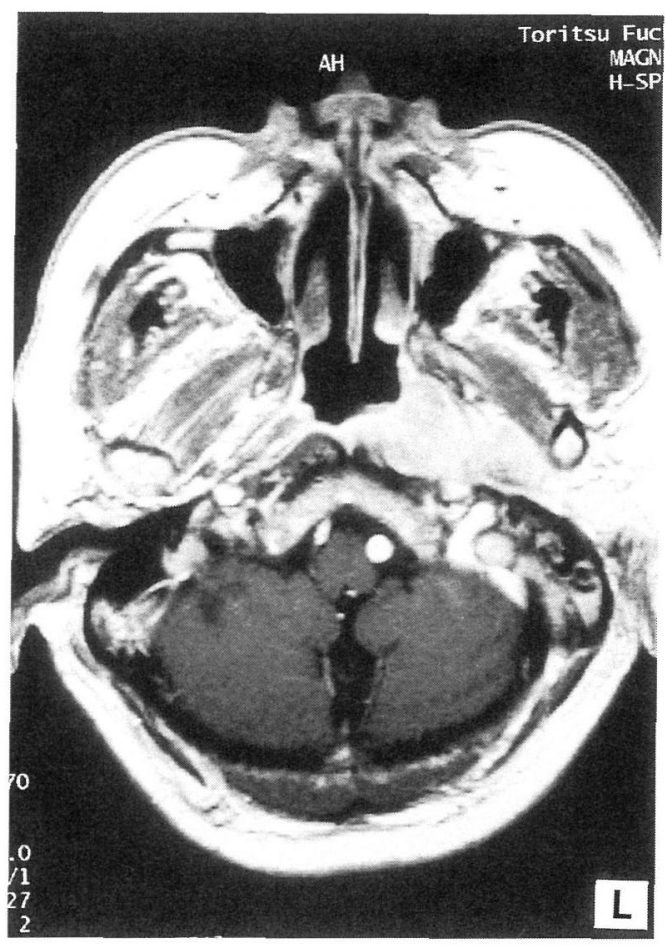

図 1 上咽頭 T1 強調 Gd-DTPA 造影 MRI 左ローゼンミニラー窩から深部に浸潤する Gd-DTPA 造 影剂に造影される領域を認める。

11 月から平成 9 年 1 月まで，上咽頭拉上び頸部に計 70 Gyの照射が行われた。放射線治療終了時, 上咽頭, 頸 部に腫瘍の残存は認められなかった。

平成 10 年 8 月, 左足第 1 指に知覚低下が出現した。知 覚低下は徐々に進行し, 両下肢から大腿にまで広がり, 下肢脱力，膀胼・直腸障害も出現したため，上咽頭腫瘍

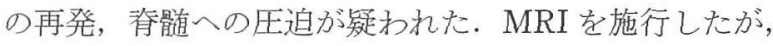
腫瘍の再発は認められなかった。平成10年10月，当院神 経内科を受診し，放射線瓷䯣症と診断され，プレドニン の内服治療が 4 週間行われたが神経症状は徐々飞進行し た. 平成11年 4 月頃より曣下障害が出現, 神経症状が進 行するため, 再度 MRIを施行した。上咽頭に腫瘍の再 発を認めたが，䀺䯣を圧迫する所見は認められなかった (図2).

再発した腫瘍の増大, 神経症状の進行は緩徐で車椅子 による外出は可能であり, 平成 11 年 10 月現在, 担癌状態 で生存している.
考察

放射線照射による凎䯣障害は，1）照射終了後 2 週間 から10カ月の比較的短期に手足の知覚低下などが出現し, 仰臥位で頸部を受動的に前屈した際に背部から下肢に電 撃様の疼痛が下降するLhermitte徵候を伴うこともあ るものの, 乞の後 3 力月前後で消失する一過性放射線猆 髄症と，2）照射終了後 3 力月から数年の潜伏期を経て 横断性, あるいは半横断性脊䯣症状であるBrown-Séquard 症候群が出現, 徐々に進行し, 膀胱・直腸障害や 呼吸障害を呈する予後の悪い晚発性放射線筒䯣症の 2 つ に大別されている2)．Palmer³) 㳊射線沓髄障害の臨床 像を 5 つの型に分類し, そのらち最も頻度の高い緩徐な 進行性の病型を, 慢性進行性放射線脊髄症と分類した。

上記の晚発性放射線资髄症と慢性進行性放射線背䯣症方 放射線脊髄症とされている。

放射線答䯣症の診断には，一般に1961年に Pallis ら が提唱した以下の 3 項目の診断基準が用いられている.

1）沗䯣が照射野に含まれていること,

2 ) 神経学的主病巣が照射を受けた资髄節中に含まれ ていること，

3）ミェログラフィーあるいは剖検により腫瘍の転移 による沗髄圧迫が否定でさること．

最近では，ミエログラフィーと代わって侵襲の少ない MRIが用いられている。放射線脊髄症の病因としては, 放射線照射による微小血管の血行障害に伴う二次的な神 経組織壤死と考光られて物り5)，MRIでは，尙䯣を圧迫 する腫瘍の否定の他に障害部位に一致した筒䯣の萎縮像, 浮腫に伴う $\mathrm{T} 2$ 強調画像での髄内の高信号域の存在, 未。 よび脳・血管関門の破壞による Gd-DTPA での増強像 など，沗髄に括ける神経変性の程度も示すことができる ため6)，今後診断基準に追加されるものと思われる. 本 症例では, 頸部脊䯣は放射線照射野に含ま机て扮り, 同 部の答䯣障害と考党られる神経症状が長期にわたり進行 していたこと，また，MRIでは脊髄の変性を示す所見 は得られなかったが, 再発した腫瘍による脊髄の圧迫が 否定されることから放射線脊䯣症と診断された。

上咽頭癌に対する放射線治療後の合併症としては口腔 内乾懆, 歯牙障害, 渗出性中耳炎, 脊髄症などが知られ ている、それらのなかでも凖䯣症は最も重篤な合併症で 岕るにもかかわらず放射線筒髄症の報告は少ない，Ballantyne ${ }^{1)}$ は218例のらち 8 例 (3.7\%) 飞放射線脊䯣症の 出現をみたと報告しているが，上咽頭癌は遠隔転移が多 


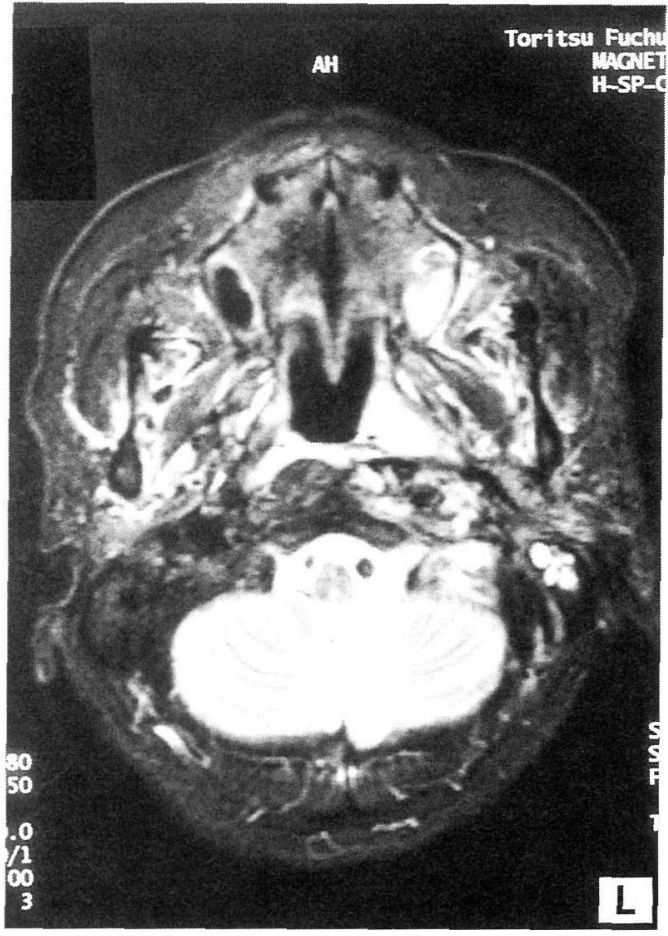

(a)

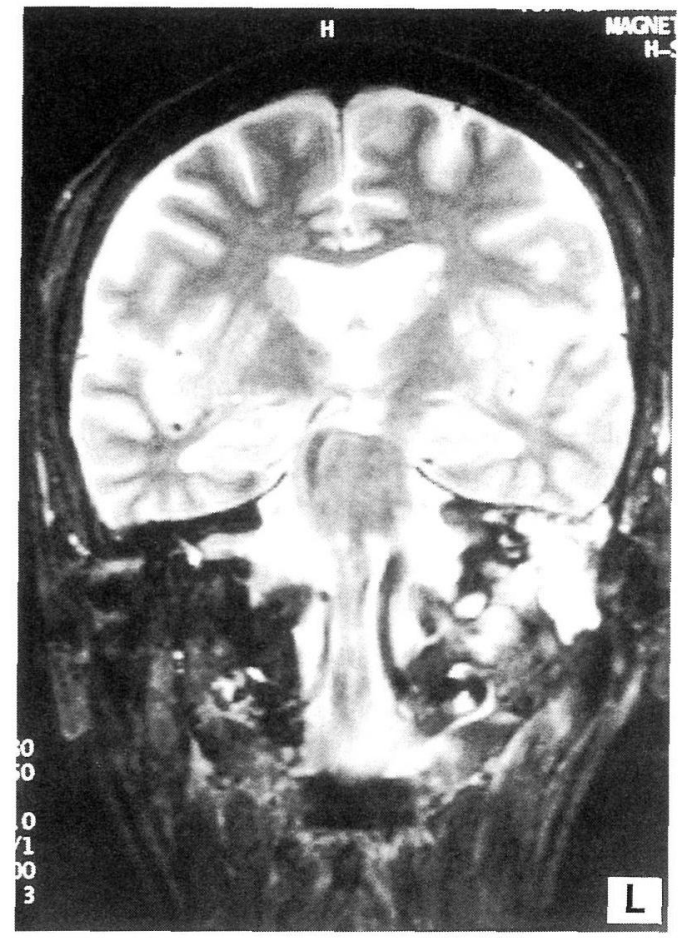

(b)

図 2 神経症状出現後の T2 強調 MRI

(a) 左ローゼンミュラー窩から深部に浸潤する高信号域を認め，上咽頭癌再発と診断された。 腫瘍の頸髄への圧迫は認められなかった。

(b) 頸部背䯣の変性は認められなかった。

く，本邦の最近の報告でも 5 年生存率が $51.3 \sim 60.6 \%$ と 予後の悪い疾患であり7) 9), 早期の癌死症例が多く, 発 症前に癌死に至っている症例が多いためと考光られてい る. 放射線療法, 化学療法, 外科的療法を組又合わせた 集学的治療の進歩により上咽頭癌症例の生存率の向上が 期待されて和り10)，予後の改善に伴って本症例のよらな 放射線障害の出現頻度が増加するものと考㝋られる。

放射線资髄症に対する有効な治療法はいまだ確立され てはいない、ステロイド㶡投与による改善例の報告も㐫 るが5)，本症例ではプレドニンの内服を 4 週間行ったに もかかわらず，神経症状の進行を止めることはできな かった，今後症例を重社，治療法を確立する必要がある と思われる。

な括本症例では，治療前に放射線资髄症についての説 明が不十分であるして，患者から連日苦情を受忖，そ の後の治療に支障をきたすこともあった。今後，放射線 资髄症が増加寸ることが予想され，放射線治療の合併症
の十分な理解が得られるよう,より一㞗の努力が必要で あることを痛感した。

$$
\text { まとめ }
$$

上咽頭癌に対して許容量である $70 \mathrm{~Gy}$ の放射線治療 を行った後，19力月後に発症した放射線资髄症例を経験 した。頸髄は放射線照射野に含まれており，同部の金髄 障害と考えられる神経症状が長期にわたり進行し, MRI により再発した腫瘍による资䯣の圧迫が否定され ることから放射線资髄症と診断した。再発した腫瘍の増 大，神経症状の進行は緩徐で車椅子による外出は可能で あり, 平成11年10月現在, 担癌状態で生存している.

\section{謝辞}

稿を終えるにあたり，ご協力頂いた東京都立府中病院耳鼻咽 喉科の今内 豊医師, 藤城芳徳医師, 看護部の水城小百合主任 に感謝致します。 


\section{参考文献}

1) Ballantyne AJ : Late sequelae of radiation therapy in cancer of the head and neck with particular reference to the nasopharynx. Am J Surg $130: 433 \sim 436,1975$.

2 ）豊倉康夫 : 神経内科学書(豊倉康夫編). 848～851頁, 朝倉 書店, 東京, 1987.

3 ) Palmer JJ : Radiation myelopathy. Brain $95: 109 \sim 122$, 1972.

4) Pallis CA, Louis S and Morgan RL : Radiation myelopathy. Brain 84 : 460 479, 1961.

5 ) Godwin-Austen RB, Howell DA and Worthington B : Observations on radiation myelopathy. Brain $98: 557 \sim 568$, 1975.

6 ）榎本浩幸, 佃守, 河野英浩, 他 : 放射線脊䯣症を合併 した上咽頭癌の 1 例. 耳喉頭頸 $67: 761 \sim 764,1995$.
7 ）八尾和雄, 高橋廣臣, 岡本牧人, 他 : 上咽頭癌51症例の治 療成績. 日耳鼻 $96: 1438 \sim 1446,1993$.

8 ) 藤井 守, 平川勝洋, 鈴木 衞, 他: 上咽頭癌の臨床的観 察 一当科15年間の集計一. 耳鼻臨床 補72:43 50, 1994.

9 ) 角田玲子, 竹生田勝次, 西嶌 渡, 他: 上咽頭癌の治療成 績と予後因子一埼玉県がんセンター18年間の検討一. 耳 喉頭頸 $67: 305 \sim 309,1995$.

10）兵頭政光, 湯本英二：上咽頭癌の治療成績 一追加手術の 有用性について一。目鼻 $101: 1227 \sim 1233,1998$.

$$
\left.\begin{array}{l}
\text { 原稿受付 : 平成11年11月 } 8 \text { 日 } \\
\text { 原稿採択 : 平成11年12月 } 8 \text { 日 } \\
\text { 別刷請求先 : 坂本雅之 } \\
\text { 干130-0022 東京都墨田区江東橋4-23-15) } \\
\text { 東京都立墨東病院耳鼻咽喉科 }
\end{array}\right)
$$

